\title{
RECONSTRUCTION OF LAW ENFORCEMENT OF MONEY POLITC IN REGIONAL HEAD ELECTION BASED ON PROGRESSIVE LAW CASE STUDY IN TEGAL CITY, SEMARANG AND PEMALANG DISTRICT
}

\author{
Imawan \\ Lecturer Pancasakti University, Tegal, Central Java, Indonesia \\ imawanimawan777@gmail.com
}

\begin{abstract}
Elections, both presidential/vice-presidential elections, legislative bodies both at the center and in the regions until the regional head are colored by money politics, as a way of winning a presidential, legislative body or regional head candidate. A democracy that should be able to choose qualified candidates for leaders, in the presence of dirty practices such as money politics, produces only a leader who is indifferent to the people and corrupt. Approach methode is juridical sociological research, where is the primary data from interview with people and secondary data from library research. Law enforcement of money politics continues to be pursued, although the results are not maximized due to obstacles, both in terms of legal substance, legal structure, and legal culture. Progressive law is an alternative in solving the money politics problem, with the courage of law enforcers in the police, prosecutors, judges and other related institutions to enforce the election law through the judicial process and the imposition of strict criminal and administrative sanctions.
\end{abstract}

Keywords : Law Enforcement, Money Policy, and Progressive Law

\section{A. INTRODUCTION}

The reform movement has given rise to new hope for the Indonesian people to be able to restore the realization of the rule of law in the social, state and state of society that upholds the values of democracy, freedom and openness and justice. Enforcement of the rule of law based on the values of truth and justice and respect for human rights has been universally degraded. This condition is partly caused by the many laws and regulations made by the government that do not reflect the aspirations of the people and the needs of development which are based on cultural, religious and community law.

According to $\mathrm{S}$ a tjipto Rahardjo, law enforcement does not take place in a vacuum or social vacuum, meaning that the absence of unlawful processes is simultaneously direct in the community. The processes such as economy and politics, law enforcement processes take place in the midst of the running of these processes. ${ }^{1}$

Satjipto R ah a rdjo, 2009, Penegakan Hukum di Tengah Keti $d$ ak a dilan, dalam Karolos Kopong Medan dan Frans J. Rengka (Ed.), Sisi-Sisi Lain Hukum di Indonesia, Kompas, Jakarta, p. 180.
This is also in line with Lawrence M. Friedman's thought, "Rules of law and process law, to repeat, are product of power. They also define power, and they instruct how power can be used ".2

Law enforcement that has been implemented in the life of society, nation and state has not been fully understood and lived by all levels of society to the legal system prevailing in Indonesia. This loss of trust has led to a public confidence in the law, which is partly caused by the many cases of corruption, collusion and nepotism (KKN) which, among other things, are caused by the overwhelming number of cases and unresolved violations of human rights.

In today's society the law has been used as an instrument of justification in achieving the goals of a group of people, groups and political elites to justify any means in achieving certain objectives, including money-giving practices or other material whose relation to influence voters elected as regional head/deputy head of region in general election of regional head.

\footnotetext{
2 Lawrence M. Friedman, 1975, The Legal System A Social Sc $i$ en c e Perspective, Russel Sage Foundation, New York, p. 169.
} 
The practice of giving money or other material which became known as money politics in the global era has now entered all the joints of social life, nation and state ranging from being able to occupy positions in bureaucrats up to occupy certain political elite positions, for example DPR, DPRD, and regional head.

Violations and weaknesses that can mislead or bias the essence of democracy especially to the people in the region in the issue of local elections that have been underway must be evaluated and improved.

Fraud and disrespectful acts in regional head elections such as money politics, stolen campaigns, and black campaigns are still coloring the election process.

Law enforcement of the prohibition of giving money or other materials to influence voters in both the legislative and general elections of the regional head although in practice is invisible and no longer has a public secret, but law enforcement felt very weak. Rarely even may never happen, law enforcement is done against the candidate of head of region and also the representative who is caught doing the giving of money or other material known as money politics to win their partner is done transparently, let alone get to court. During this time only a certain individual who happens to be caught hand giving money or distributing food from the prospective spouse to the community head.

According to Ali Mansyur that chaotic law enforcement in the reform era will not be completed if each run on personal interests both from the authorities and the community. ${ }^{3}$

In the effort to increase law enforcement to prevent money or money politics to uphold democracy encountered several problems arise, among others: (1) weakness of legal material; (2) low awareness and legal obedience, (3) low moral and ethical apparatus (law enforcement, political elite, and society); and (4) the low level of welfare. ${ }^{4}$

Law enforcement is not just a logical process, not only seen as a linear process, but also the

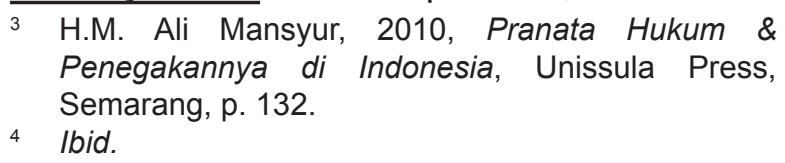

inclusion of the human factor makes the law laden with the dimensions of behavior along with the factors that go with it. Law enforcement is done by police, prosecutors and government officials, because the law contains the command, but it takes human action to realize the command. ${ }^{5}$

Law enforcement essentially contains supremacy of substantial value, which is justice. The issue of law enforcement is a matter that is not simple, not only because of the complexity of the legal system itself, but also the complexity of the relationship between the legal system and the social, political, economic and cultural systems of society. ${ }^{6}$ From this cases, so what are the factors that influence the enforcement of money politics law in the current regional head elections. What are the shortcomings of law enforcement of money in the current regional heads election. What is the reconstruction of money-politics law enforcement in the election of a progressive, law-based regional head.

\section{B. DISCUSSION}

1. Factors influencing the law enforcement of money politics in the current regional head elections;

Money politics in Bahasa Indonesia is a suap (bribe), while the meaning of suap in the Indonesian General Dictionary is bribery. ${ }^{7}$ Yusril Ihzha Mahendra states that money politics the election period with material rewards. ${ }^{8}$

Money politics is common in elections in Indonesia. Money politics can also be done with goods such as sembako (daily needs) in the form of: rice, cooking oil, tea and instant noodles as well as tools of prayer and so forth. Money politics is usually done by sympathizers, cadres or even political party officials either at the time of socialization, campaign or in the morning before Election Day.

5 Indrati Rini, 2013, Perkembangan Pemikiran Sosiologi Hukum, Program Doktor IImu Hukum Universitas Islam Sultan Agung Semarang,

6 H.M. Ali Mansyur, op.cit., p. 69.

7 Departemen Pendidikan Dan Kebudayaan, 1994, Kamus Besar Bahasa Indonesia, Edisi Kedua, Balai Pustaka, Jakarta, p. 965.

8 Indra Ismawan, 1999, Money Politics Pengaruh Uang Dalam Pemilu, Media Presindo, Yogyakarta, p. 4. 
Money politics is an instant way to achieve power and is a healthy competition by dedicating the hard work and struggle of the right candidates and obedient to the real democratic processes and values. ${ }^{9}$

According Teguh Yuwono there are several effects of money politics, namely: First, is the rise of corrupt leaders. The logic is simple, whoever becomes the leader (regent, mayor, or governor) for buying votes or spending a lot of money to get the position, then he/she will definitely try to return the money or capital. Corruption will get worse if the dreamer is in debt or depressed political agreement ahead of the election. Leaders who are in debt to win political competence through elections will have a tendency to abuse power to get any money or resources to recover the capital or debt. In the perspective of the Public Choice Theory is an emphasized, political individual will always maximize personal interests so that corrupt tendencies must be very high. Motivation maximizes personal interests, can be money, or collusion and nepotism. Corruption, collusion, and nepotism are the clearest mode of maximizing personal interests as a result of money politics and black camps. Second, money politics produces instant leaders who will not be able to manage the government. In other words, they will manage the government as it is, without commitment, and consistency to bring about prosperity and justice. ${ }^{10}$

Electoral law, both presidential and vice-presidential elections, DPR, DPD and DPRD as well as regional head elections prohibit the existence of money politics or the provision of money and other materials.

Criminal law enforcement of money politics in the election of regional heads and deputy regional heads, both in the election of regional heads-deputy head

9 Teguh Yuwono, Efek Politik Uang dan Kampenye Hitam, Suara Merdeka, 8 Desember 2015, p. 4.

10 Ibid. of the region based on Law Number 32 Year 2004 on Regional Government, during the election of Regional Head from 2005 to 2012 the application of the law very weak and unable to prevent or even eliminate the existence of money politics.

According to Abhan, Chairman of the Central Java Election Supervisory Board, said that with the change of rules on the election of regional heads, there is one thing that concerns many people and election supervisors, namely the absence of legal sanctions for perpetrators of political bribery or popular practice called money politics in the Law on the Election of Regional Head. In his opinion there is a prohibition for political parties who receive rewards in the nomination process which in practice is called "dowry", whereas the "dowry" is prohibited by the candidate head of the region to the political party. ${ }^{11}$

The weaknesses of both criminal sanctions and the absence of administrative sanctions in the General Election Law are in the form of cancellation of candidates for regional heads-deputy heads of regions by the Provincial, Regency and / or Municipal General Election Commission to make politics to distribute money or other goods to be fertile and become it is reasonable for every election. Due to the absence of such sanctions, law enforcement in money politics or other materials cannot be properly carried out by the existing legal apparatus.

The weak regulation on law enforcement in both criminal and state administration is still supplemented by the General Elections Regulation made by the Election Commission. Regulations such as Rule Number 7 of 2015 on the Election of Governor and Deputy Governor, Regent and Deputy Regent, and / or Mayor and Deputy Mayor May

11 Interview with Abhan Misbah, Ketua Badan Pengawas Pemilu Jawa Tengah, on 16 November 2015. 
Revise in Article 26 has allowed candidate pairs and / or campaign team to create and print as well as the distribution of campaign materials that includes the highest shirt, mug, calendar, name-card, pin, ballpoint, umbrella and/or sticker 10x5 $\mathrm{cm}$ if converted in the form of money the highest value Rp25.000, - (twenty five thousand rupiah).

Weak law enforcement in the violation of money politics during the election of regional heads in addition to the substance, namely the weakness of legal materials and legal strata, namely the low moral and ethical law enforcement is also influenced by the culture of community law in the form of disobedience and legal awareness of the community. Although they know that the provision of money or other materials to vote for a particular candidate in the election of regional heads is prohibited, but both the community and the candidate of the regional head and the successful team and the campaign team continue to commit such violations. The community assumes when it can enjoy the sustenance of candidates for regional heads-vice regional heads if not now when they need their voice, but not necessarily the people who receive the money or materials choose the candidate of the region head.

The low awareness and legal compliance of citizens, especially for the lower middle class of society, are still willing to receive rewards as a lure for them to choose a particular candidate. On the one hand, there is also a perception of society when the candidate head of the region needs their voice as legitimacy to become head of the region, but the community also assumes when the candidate of the regional head is elected, they are pessimistic the head of the area is still thinking of them.

The condition of Indonesian society today is still felt very apprehensive. The large numbers of people who have not yet earned proper welfare for their survival have become one of the causes of money politics in every election, both presidential and vice-presidential elections, DPR and DPRD, regional heads-deputy regional heads and village heads. The lack of employment, uneven development and population density in each region has become one of the most common causes of unemployment in Indonesia.

\section{The shortcomings of law enforcement of money politics in the current regional head elections;}

There are several weaknesses of law products related to the practice of money politics, especially the rules of money politics in elections of regional heads, they are, Article 82 of Law Number 32 Year 2004. The weakness in this provision is when it is known that there is a candidate pair of regional head- or his campaign team promises or gives money or other materials to the voters. The people elect a candidate for the head of the regional head-the deputy head of the region concerned and subsequently proven that the act violates the criminal provisions and then the proceedings are continued up to the District Court hearing. Subsequently the District Court ruled that the candidate pair or his campaign team was guilty and imposed a criminal sanction on him, then by the decision of the District Court the House of Representatives could cancel the candidate pair of regional head-the deputy head of the region referred to in the election of the regional head-the deputy head of that time. The disadvantage to the sanction of this cancellation is to require a Decision of the Regional People's Legislative Assembly in which the regional head-the deputy head of the region shall elect the regional head-the deputy head of the region. The requirement of the Decision of the Regional Representative Council is not an easy job and may be very complicated, as it involves also political decisions. Surely the Regional 
People's Legislative Assembly that will cancel one of the candidates of regional head-deputy head of region, must first hold bargaining position with the party and other factions, especially when that will be canceled is a candidate pair of regional head-deputy head of the region in stretcher by his party alone or coalition with other parties. Not necessarily the hearing to take the decision of the split of candidates for regional head-deputy head of the region runs smoothly.

The center of Integrated Legal Movement in each province, district and city formed jointly by the Provincial Election Supervisory Board as well as the Election Supervisory Committee of Regency / City, was also not much function in expressing and following up the findings of money politics or money or material others in the election of regional heads-deputy head of the region.

Law Number 1 Year 2015 jo. Law No. 8 of 2015 does not strictly regulate sanctions for criminal offenses of money politics or the provision of money or other materials whether conducted by candidates for regional heads-vice regional heads and campaign teams. The weak regulation on sanctions in transactional political law enforcement or money politics in every election of regional heads becomes a constraint to the enforcement of these violation laws.

\section{Reconstruction of law enforcement of money politics in the election of regional heads based on progressive law.}

Every nation wants to stand firm and know clearly which the goal is to achieve a very important view of life. With this view of life a nation will look at the problems it faces and determine the direction and way in which the nation solve those problems. Without a view of life, a nation will feel continue to oscillate in the face of major problems that must arise, both the problems within the community itself and the big problems of human beings in the community of the peoples of the nations in this world. ${ }^{12}$

Pancasila for the nation of Indonesia is a view of life, awareness and moral aspirations that include psychology and character that has been rooted in the culture of the Indonesian nation. This is the culture that teaches that human life will achieve happiness if it can be developed harmony and balance, both in the relationship of human life as a person, in human relationships with society, in human relationships with nature, in human relationships with $\mathrm{God}$, and in the pursuit of external progress and happy soul. ${ }^{13}$

Consequently, the implementation of the state, especially all laws and regulations, including the reform process in all fields today, is defined and derived from the values of Pancasila. Pancasila is the source of all legal sources (the source of Indonesian law). Pancasila is the source the law of the state constitutionally governs the Republic of Indonesia and all its elements, namely the people, the territory and the government of the country. ${ }^{14}$

With the enactment of Pancasila as the legal ideals and also the fundamental norm of the state, the Indonesian legal system, whether in its formation, in its application or in its enforcement, cannot self-dissolve from Pancasila values as constitutive and regulative legal ideals, the provisions of Pancasila as the highest norm that determines the legitimacy of a legal norm within the legal system of the Republic of Indonesia. ${ }^{15}$

12 A.W. Widjaja, 1986, Pedoman Pokok-Pokok Materi Perkulianan Pancasila Pada Perguruan Tinggi, Akedima Pressindo, Jakarta, p. 173.

13 Ibid., p. 174.

14 H. MS. Kaelani, 2013, Negara Pancasila Kultural, Historis, Filosofis, dan Aktualisasinya, Paradigma, Yogyakarta, p. 472.

15 A. Hamid. S Attamimi, 1990, Peranan Keputusan Presiden Republik Indonesia Dalam Penyelenggaraan Pemerintahan, Disertasi Doktor IImu Hukum, Fakultas Pasca Sarjana, Universitas Indonesia, Jakarta, p. 359. 
In criminal law enforcement, especially in the issue of money politics or the giving of money and other materials in the general election, includes the election of regional heads of law enforcement problems against law-breakers, especially the money politics issue. However, law enforcement is limited to money politicians whose perpetrators are only small communities. Rarely happens and even never done political law enforcement of money imposed to prospective spouses of regional heads. The requirements for the existence of formal evidence and material evidence required by Police investigators of the Republic of Indonesia, especially incorporated in the center Integrated Legal Movement (Gakumdu in Indonesia), are very difficult to meet by the Committee or the Election Supervisory Board. On the one hand there have been no perpetrators who were caught red-handed by carrying billions of rupiah. Perhaps, if someone could be caught with billions of rupiah, there might be a suspicion that the perpetrator or perhaps the one who was putting the candidate in the head of the regional head. However, during this time that can be caught hands only the perpetrator of money between Rp10.000, - (ten thousand rupiah) to Rp50.000, (fifty thousand rupiah), so it is difficult to reach who the actors who make money in every the holding of regional head elections. ${ }^{16}$

Required law enforcement officers who dare to take the initiative to further reveal the role of money-giving actors or other materials in such cases. Progressive law needs to be applied to change the pattern of law enforcement of money politics or the provision of money and other materials in the election of regional heads. Law enforcement officers consisting of Election Supervisory Committee, Police, and State Attorney as well as Judge at District Court who

16 Interview with Kepala Badan Pengawas Pemilu Jawa Tengah, November 2015. examined the case dared to take the initiative to change the pattern of law enforcement that has been there. This means that law enforcement officers dare to make changes to the political handling of money or other materials in every election, both presidential and vice presidential, DPR, DPRD, and DPD election included elections that have been going on. Without a change of attitude from the law enforcement officers undoubtedly the issue of money politics will continue to grow until whenever it has been done by the community. In addition, it is accompanied by progressive decisions of the local Electoral Commission to cancel the candidates for regional heads. For whatever reason the criminal law enforcement of both prisons and fines imposed on perpetrators of money politics or giving money in each election of regional heads, it did not make a deterrent for other actors to do the same thing even in different periods.

The process of law enforcement of money politics is solved with Completed Theory Case (Teori Tuntas Perkara), meaning that the process of law enforcement against money politicians should be done completely thoroughly not only by criminalizing the perpetrators, but the imposition of administrative sanctions, namely in the form of cancellation of participation as a candidate for regional head by the Provincial Election Commission, District and City to candidates, campaign teams and other parties nominated by candidates and / or their campaign teams proven to practice money politics on the recommendation of the Provincial Election Supervisory Board, the Regency/ City Election Supervisory Committee. Thus, it will cause the cancellation as a candidate for regional head-deputy head of the region during the election of the regional head at that time.

Problems that occur and ambiguous is in the mechanism of punishment is 
the mixing of law enforcement law violations with law enforcement of criminal violation of regional head election. Law enforcement mechanisms Article 47 and 73 of Law Number 8 Year 2015 are the same as those existing in Law Number 32 Year 2004, namely the imposition of administrative sanctions made one with criminal sanction in case of money politics in the election of regional head. Reconstruction of Law Number 8 Year 2015 can be done in Articles 47 and 73 of Law Number 8 Year 2015.

\section{CONCLUSION}

Factors influencing the law enforcement of money politics in the regional head election are currently consisting of: (i) weak legal matter, (ii) mixed criminal sanctions and administrative sanctions have made law enforcement inefficient, (iii) low awareness and legal obedience society, (iv) low moral and ethical law enforcement officers also influence the enforcement of money politics practice law. Another influential factor is related to the low level of community welfare.

The shortcomings in the enforcement of money politics law in the election of regional heads, among others: (i) the existence of unambiguous sanctions regulation, let alone mixing administrative sanctions and criminal sanctions against money politicians, (ii) Law No. 1 of 2015 jo. Law Number 8 Year 2015 does not explicitly regulate sanctions on criminal violations of money politics or the provision of money or other material; (iii) administrative sanctions in the form of cancellation as candidates for regional heads-deputy heads of regions are also never applied to the occurrence of money politics ; and (iv) non-invasive factors of law enforcement officers.

The reconstruction of money politics in the election of a progressive law-based regional head is done by separating administrative sanctions in the form of cancellation of candidates for regional heads-vice regional heads proven to engage in money politics by the Provincial, Regency and Municipal General Election Commission on the recommendation of the Provincial Election Supervisory Board, District or City where the regional head elections take place and do not have to wait for the criminal process. While the process of examining criminal offenses against money politicians in the election of regional head conducted in accordance with the provisions set forth in the Criminal Procedure Code as well as other criminal investigation process. With the existence of strict administrative sanctions, namely to cancel the prospective couples head achieved in order not to follow the election of the head of the area that was done at that time makes people afraid to practice money politics. Progressive law needs to be applied to change the pattern of law enforcement of money politics or the provision of money and other materials in the election of regional heads. Law enforcement officers consisting of the Election Supervisory Committee, the Police, as well as the State Attorney and at the same time the Judge at the District Court who examined the case referred to dared to take the initiative to change the existing law enforcement pattern.

There needs to be a clear or clear definition or definition of money politics in legislation, especially the law on General Elections, at least avoidable misinterpretations of the practice of money politics.

There needs to be a separation between administrative sanctions in the form of cancellation as candidate for regional head-deputy head of region with criminal sanction of criminal violation of money politics.

The Government and the House of Representatives need to reconstruct Articles 47 and 73 of Law No. 8 of 2015 which are expected in the 2017 regional head election will run more democratically and at a cheaper cost, especially in the nomination. 


\section{BIBLIOGRAPHY}

A. Hamid. S Attamimi, 1990, Peranan Keputusan Presiden Republik Indonesia Dalam Penyelenggaraan Pemerintahan, Disertasi Doktor Ilmu Hukum, Fakultas Pasca Sarjana, Universitas Indonesia, Jakarta.

A.W. Widjaja, 1986, Pedoman Pokok-Pokok Materi Perkulianan Pancasila Pada Perguruan Tinggi, Akedima Pressindo, Jakarta.

Departemen Pendidikan Dan Kebudayaan, 1994, Kamus Besar Bahasa Indonesia, Edisi Kedua, Balai Pustaka, Jakarta.

Indra Ismawan, 1999, Money Politics Pengaruh Uang Dalam Pemilu, Media Presindo, Yogyakarta.

Indrati Rini, 2013, Perkembangan Pemikiran Sosiologi Hukum, Program Doktor Ilmu Hukum Universitas Islam Sultan Agung Semarang.

MS. Kaelani, 2013, Negara Pancasila Kultural, Historis, Filosofis, dan Aktualisasinya, Paradigma, Yogyakarta.

M. Ali Mansyur, 2010, Pranata Hukum \& Penegakannya di Indonesia, Unissula Press, 2010, Semarang.

Lawrence M. Friedman, 1975, The Legal System A Social Science Perspective, Russel Sage Foundation, New York.

Satjipto Rahardjo, 2009, Penegakan Hukum di Tengah Ketidakadilan, dalam Karolos Kopong Medan dan Frans J. Rengka (Ed.), Sisi-Sisi Lain Hukum di Indonesia, Kompas, Jakarta.

Teguh Yuwono, Efek Politik Uang dan Kampenye Hitam, Suara Merdeka, 8 Desember 2015, 